UDC 639.3.09:577.151.63:57.021

DOI 10.32900/2312-8402-2020-124-24-35

\title{
POST-VACCINATED ALTERATIONS IN THE MARKERS OF LIPID AND PROTEIN OXIDATION IN THE GILLS OF RAINBOW TROUT (ONCORHYNCHUS MYKISS WALBAUM) IMMUNIZED AGAINST THE ENTERIC REDMOUTH DISEASE
}

\author{
Tkachenko H., Doctor of Biological Sciences \\ Kurhaluk N., Doctor of Biological Sciences \\ Institute of Biology and Earth Sciences, Pomeranian University in Słupsk, Poland \\ Grudniewska J., Ph.D. \\ Department of Salmonid Research, Stanislaw Sakowicz Inland Fisheries \\ Institute, Żukowo, Poland \\ Pękala-Safińska A., Ph.D., \\ Department of Fish Diseases, National Veterinary Research Institute, Pulawy, \\ Poland
}

The aim of the study was the evaluation of the content of oxidative stress biomarkers (2-thiobarbituric-acid-reacting substances as a biomarker of lipid peroxidation, aldehydic and ketonic derivatives of oxidatively modified proteins) in the gills of rainbow trout (Oncorhynchus mykiss Walbaum) vaccinated by a vaccine against Yersiniaruckeri.

Rainbow trout (Oncorhynchus mykiss Walbaum) with a mean body mass of (107.9 \pm 3.1$) \mathrm{g}$ were used in the experiments. The study was carried out in a Department of Salmonid Research, Inland Fisheries Institute in Rutki (Poland). Experiments were performed at a water temperature of $14.5 \pm 0.5^{\circ} \mathrm{C}$ and the $\mathrm{pH}$ was 7.5. The dissolved oxygen level was about 12 ppm with additional oxygen supply with a water flow of $25 \mathrm{~L}$ per min, a photoperiod of 12 hours per day. The fish were fed with a commercial pelleted diet at an optimal level, using 12-hour belt feeders for fish. All enzymatic assays were carried out at the Department of Zoology and Animal Physiology, Institute of Biology and Earth Sciences, Pomeranian University in Stupsk (Poland). The fish were kept for 60 days after vaccination at a water temperature of $14.5 \pm 0.5^{\circ} \mathrm{C}$ and $\mathrm{pH}$ 7.5. In our study, 15 rainbow trout from unhandled control and 15 vaccinated trout were used. Two months after immunization, samples from rainbow trout were collected. The fish were captured and killed 61 days post-vaccination ( $n=15$ in each group). Gills were removed in situ. The organs were rinsed clear of blood with cold isolation buffer and homogenized using a glass homogenizer H500 with a motor-driven pestle immersed in an ice water bath to yield a homogenate in proportion 1:9 (weight/volume). The isolation buffer contained $100 \mathrm{mMTris}-\mathrm{HCl}$; a pH of 7.2 was adjusted with $\mathrm{HCl}$. Homogenates were centrifuged at 3,000g for 15 min at $4^{\circ} \mathrm{C}$. After centrifugation, the supernatant was collected and frozen at $-20^{\circ} \mathrm{C}$ until analyzed. Protein contents were determined using the method of Bradford (1976) with bovine serum albumin as a standard. Absorbance was recorded at $595 \mathrm{~nm}$. All enzymatic assays were carried out at $22 \pm 0.5^{\circ} \mathrm{C}$ using a Specol 11 spectrophotometer (Carl Zeiss Jena, Germany) in duplicate. The enzymatic reactions were started by the addition of the tissue supernatant.

Our results demonstrated that immunization by the anti-Yersinia vaccine does not alter the gills of rainbow trout. Oxidative stress parameters examined in gills homogenate, i.e., lipid peroxidation as measured by the amount of TBARS, as well as aldehydic (increased by 18.9\%) and ketonic derivatives of OMP (decreased by $6.5 \%$ ) were non-significantly changed ( $p>0.05)$ in gills of vaccinated fish. Thus, immunization 
by anti-Yersinia vaccine does not alter oxidative stress markers compared to unhandled control in the second month after immunization. Our results confirm that the vaccine against $Y$. ruckeri has no adverse effect on the condition and metabolism in the gills of the fish. Alterations in the content of oxidative stress biomarkers recorded in our studies are proof that the vaccine against Y. ruckeri has no negative effects.

Keywords: Yersinia ruckeri, the Enteric redmouth (ERM) disease, rainbow trout (Oncorhynchus mykiss Walbaum), gills, oral vaccination, 2-thiobarbituric-acid-reacting substances, aldehydic and ketonic derivatives of oxidatively modified proteins

Yersinia ruckeri is the causative agent of the Enteric redmouth (ERM) disease or yersiniosis, a serious septicemic bacterial disease of salmonid fish species $[18,38]$. The causative agent, a Gram-negative Enteric bacterium, which was first isolated in the Hagerman Valley, Idaho, USA, in the early 1950s, was described fully by Ross and coworkers (1966) and defined as a new species, Y. ruckeri, in 1978 [9]. Y. ruckeri is a member of the family Enterobacteriaceae within the gamma-proteobacteriasubdivision. Generally, of coccoid-rod cell morphology, Y. ruckericells are slightly curved, $1.0 \mu \mathrm{m}$ in diameter and 2-3 $\mu \mathrm{m}$ in length, though culture for $48 \mathrm{~h}$ or longer results in long filamentous cells [1].

The external signs of the disease include reddening of the mouth, the oral cavity, throat, anus, the base of the fins, and the area around the lateral line caused by subcutaneous hemorrhages [38]. Exophthalmia, known as 'pop-eye', usually starts unilaterally, but at later stages, both eyes can pop out of their sockets. Eventually, exophthalmia causes the eyes to rupture, which results in fish blindness [4, 18]. Hemorrhages and inflammation also occur in the liver, pancreas, swim-bladder, stomach, and muscles. The intestine is filled with a yellowish, opaque fluid. The kidney and the spleen are often swollen, and the spleen can be black [11, 18]. Septicemia symptoms in wellvascularized organs, i.e., the kidney, spleen, heart, liver, and gills are observed in the histopathological examination of infected rainbow trout tissues [3, 29, 38]. Characteristic clinical signs of yersiniosis, such as hemorrhages around the oral cavity, are causes by extracellular products (ECPs) of Y. ruckeri strains [24].

Vaccination performed by administering the vaccine (a bacterin consisting of formalin killed bacteria) by immersion, bath, or injection plays an important role in protecting salmonids against the bacterial pathogen $Y$. ruckeri [15]. Different types of adaptive responses may be on-going within the vaccinated fish during infection with $Y$. ruckeri, potentially affected by the site and stage of infection [13]. On the other hand, in recent years, there has been an increasing incidence of vaccine breakdown in salmon. For instance, Ormsby and co-workers (2016) have demonstrated that $Y$. ruckeri isolates recovered from diseased Atlantic salmon, Salmo salar L., in Scotland are more diverse than those from rainbow trout; furthermore, isolates from the two species represent distinct sub-populations. Also, a new O-serotype was identified that is responsible for a significant proportion of Atlantic salmon disease. This is largely because current vaccines are aimed at rainbow trout and based on serotypes specific for this species. A wider range of serotypes is responsible for infection in Atlantic salmon but very little is known about the diversity of these strains and their relationships to those recovered from rainbow trout [22].

ERM is traditionally associated with rainbow trout [22]. Vaccination of rainbow trout against ERM by immersion in $Y$. ruckeri bacterin confers a high degree of protection to the fish [28]. ERM has been controlled successfully using immersion-applied bacterin vaccines for several decades [37]. Oral administration is "the ideal method" for 
administering vaccines to fish whereby the vaccine is incorporated into fish feed. It is less labor-intensive than injection and immersion and is suitable for vaccinating large numbers of fish of all sizes. It avoids the handling stress experienced by the fish with the other two methods. The major disadvantage with this route of administration is that lower levels of protection are achieved and the duration of protection elicited is shorter [32].

Many studies have been carried out to examine the efficacy of oral vaccines in fish [26]. These studies have looked at the types of immune responses stimulated by oral vaccination and the levels of protection obtained, but varying degrees of success have been reported in the literature. These variations are believed to be due to differences in experimental design between studies, including antigen preparation, the age and species of fish, the water temperature at the time of vaccination, duration of vaccine feeding, and antigen integrity when it reaches the hindgut [32].

Despite the importance and success of vaccination against bacterial diseases in fish, little is known about the mechanisms of vaccine-induced alterations in the content of oxidative stress biomarkers (2-thiobarbituric-acid-reacting substances as a biomarker of lipid peroxidation, aldehydic and ketonic derivatives of oxidatively modified proteins). In this study, an efficacious bacterial vaccine, Enteric redmouth Disease (ERM), was used to vaccinate rainbow trout, and sixty days later the fish were sampled for the study.

Materials and methods. Experimental animals. Rainbow trout (Oncorhynchus mykiss Walbaum) with a mean body mass of $(107.9 \pm 3.1) \mathrm{g}$ were used in the experiments. The study was carried out in a Department of Salmonid Research, Inland Fisheries Institute in Rutki (Poland). Experiments were performed at a water temperature of $14.5 \pm 0.5^{\circ} \mathrm{C}$ and the $\mathrm{pH}$ was 7.5 . The dissolved oxygen level was about $12 \mathrm{ppm}$ with additional oxygen supply with a water flow of $25 \mathrm{~L}$ per min, a photoperiod of 12 hours per day. The fish were fed with a commercial pelleted diet at an optimal level, using 12hour belt feeders for fish. The daily dose of feed is calculated by the applicable table feed [10]. All enzymatic assays were carried out at the Department of Zoology and Animal Physiology, Institute of Biology and Earth Sciences, Pomeranian University in Słupsk (Poland).

Experimental design. The fish were divided into two groups: I) unhandled control, II) fish immunized by the vaccine against Y. ruckeri. Fish were held in 1000-L square tanks (150 fish per tank) in the same environmental conditions. The vaccine was produced in the Department of Fish Diseases, National Veterinary Research Institute in Pulawy (Poland). The vaccine against ERM was prepared from formalin-inactivated cells of $Y$. ruckeri. The vaccine contains three $Y$. ruckeri strains originating from rainbow trout cultured on the different farms, where fish exhibited clinical signs of ERM. All bacteria isolates belonged to $\mathrm{O} 1$ serotype biotype 2 that are pathogenic in fish and showed some differences in their biochemical properties. The bacterial strains were inoculated onto trypticase soy broth (TSB, BioMerieux) and incubated for $48 \mathrm{~h}$ at $24^{\circ} \mathrm{C} \pm 1^{\circ} \mathrm{C}$. After incubation, the purity of the culture was checked. The density of the vaccine was estimated spectrophotometrically, and formalin was added to the final concentration of $0,4 \%$ to inactive the bacterial strains. Vaccine sterility control was performed after the $48 \mathrm{~h}$ incubation period. Prepared vaccine at the concentration of $1 * 10^{9}$ cells per $\mathrm{mL}$ was used to inoculate fish per os. Vaccine concentrate was added to fish feed and administered three times with a one-day interval in between feedings.

The fish were kept for 60 days after vaccination at a water temperature of $14.5 \pm 0.5^{\circ} \mathrm{C}$ and $\mathrm{pH}$ 7.5. In our study, 15 rainbow trout from unhandled control and 
15 vaccinated trout were used. Two months after immunization, samples from rainbow trout were collected.

Sampling. The fish were captured and killed 61 days post-vaccination ( $\mathrm{n}=15$ in each group). Gills were removed in situ. The organs were rinsed clear of blood with cold isolation buffer and homogenized using a glass homogenizer H500 with a motordriven pestle immersed in an ice water bath to yield a homogenate in proportion 1:9 (weight/volume). The isolation buffer contained $100 \mathrm{mMTris}-\mathrm{HCl}$; a $\mathrm{pH}$ of 7.2 was adjusted with $\mathrm{HCl}$. Homogenates were centrifuged at $3,000 \mathrm{~g}$ for $15 \mathrm{~min}$ at $4^{\circ} \mathrm{C}$. After centrifugation, the supernatant was collected and frozen at $-20^{\circ} \mathrm{C}$ until analyzed. Protein contents were determined using the method of Bradford (1976) with bovine serum albumin as a standard. Absorbance was recorded at $595 \mathrm{~nm} \mathrm{[2].} \mathrm{All} \mathrm{enzymatic} \mathrm{assays}$ were carried out at $22 \pm 0.5^{\circ} \mathrm{C}$ using a Specol 11 spectrophotometer (Carl Zeiss Jena, Germany) in duplicate. The enzymatic reactions were started by the addition of the tissue supernatant. The specific assay conditions were as follows.

Assay of 2-thiobarbituric acid reactive substances (TBARS). An aliquot of the homogenate was used to determine the lipid peroxidation status of the sample by measuring the concentration of 2-thiobarbituric-acid-reacting substances (TBARS), according to Kamyshnikov (2004) [16]. Reaction mixture consisted of a sample homogenate $(2.1 \mathrm{~mL}, 10 \% \mathrm{w} / \mathrm{v})$ in Tris-HCl buffer $(100 \mathrm{mM}, \mathrm{pH}$ 7.2), 2-thiobarbituric acid (TBA; $0.8 \%, 1.0 \mathrm{~mL}$ ), and trichloracetic acid (TCA; $20 \%, 1.0 \mathrm{~mL}$ ). The total volume was kept in a water bath at $100^{\circ} \mathrm{C}$ for $10 \mathrm{~min}$. After cooling, the mixture was centrifuged at $3,000 \mathrm{~g}$ for $10 \mathrm{~min}$. The absorbance of the supernatant was measured at $540 \mathrm{~nm}$. TBARS values were reported as nmoles malonic dialdehyde (MDA) per mg protein.

Assay of carbonyl groups of the oxidatively modified protein. Carbonyl groups were measured as an indication of oxidative damage to proteins according to the method of Levine and co-workers (1990) [20] in the modification of Dubinina coworkers (1995) [8]. Samples were incubated at room temperature for $1 \mathrm{~h}$ with $10 \mathrm{mM}$ 2,4-dinitrophenylhydrazine (DNTP) in 2M HCl. Blanks were run without DNTP. Afterward, proteins were precipitated with TCA and centrifuged for $20 \mathrm{~min}$ at 3,000 g. The protein pellet was washed three times with ethanol: ethyl acetate (1:1) and incubated at $37{ }^{\circ} \mathrm{C}$ until complete resuspension. The carbonyl content could be measured spectrophotometrically at $370 \mathrm{~nm}$ (aldehydic derivatives, $\mathrm{OMP}_{370}$ ) and $430 \mathrm{~nm}$ (ketonic derivatives, $\mathrm{OMP}_{430}$ ) (molar extinction coefficient $22,000 \mathrm{M}^{-1} \cdot \mathrm{cm}^{-1}$ ) and expressed as nmol per mg protein.

Statistical analysis. Data were presented as the mean \pm S.E.M. and were checked for assumptions of normality using the Kolmogorov-Smirnov one-sample test and Lillieforstests $(\mathrm{p}>0.05)$. To find significant differences (significance level, $\mathrm{p}<0.05$ ) between control and vaccinated groups, the Mann-Whitney $U$ test was applied to the data [39]. Differences were considered significant at $\mathrm{p}<0.05$. The relationships between oxidative stress biomarkers of all individuals were evaluated using Spearman's correlation analysis. All statistical analysis was performed by STATISTICA 8.0 software (StatSoft, Krakow, Poland).

Results and discussion. The level of lipid peroxidation in the gills of trout treated by a vaccine against $Y$. ruckeri $\left(246.49 \pm 22.78 \mathrm{nmol} \cdot \mathrm{mg}^{-1}\right.$ protein) did not significantly differ from that in the controls $\left(245.06 \pm 34.47 \mathrm{nmol} \cdot \mathrm{mg}^{-1}\right.$ protein $)$. The content of ketonic derivatives of oxidatively modified proteins in the gills was nonsignificantly decreased in the group vaccinated against $Y$. ruckeri at the second month $\left(216.75 \pm 28.26 \mathrm{nmol} \cdot \mathrm{mg}^{-1}\right.$ protein) compared to the unhandled group (182.34 \pm $23.55 \mathrm{nmol} \cdot \mathrm{mg}^{-1}$ protein). The aldehydic derivatives of OMB in gills of fish treated by the vaccine against $Y$. ruckeri at 61 days after immunization $\left(273.27 \pm 37.98 \mathrm{nmol} \cdot \mathrm{mg}^{-1}\right.$ 
protein) was non-significant higher compared to unhandled control $(292.10 \pm$ $28.74 \mathrm{nmol} \cdot \mathrm{mg}^{-1}$ protein) (Fig. 1).

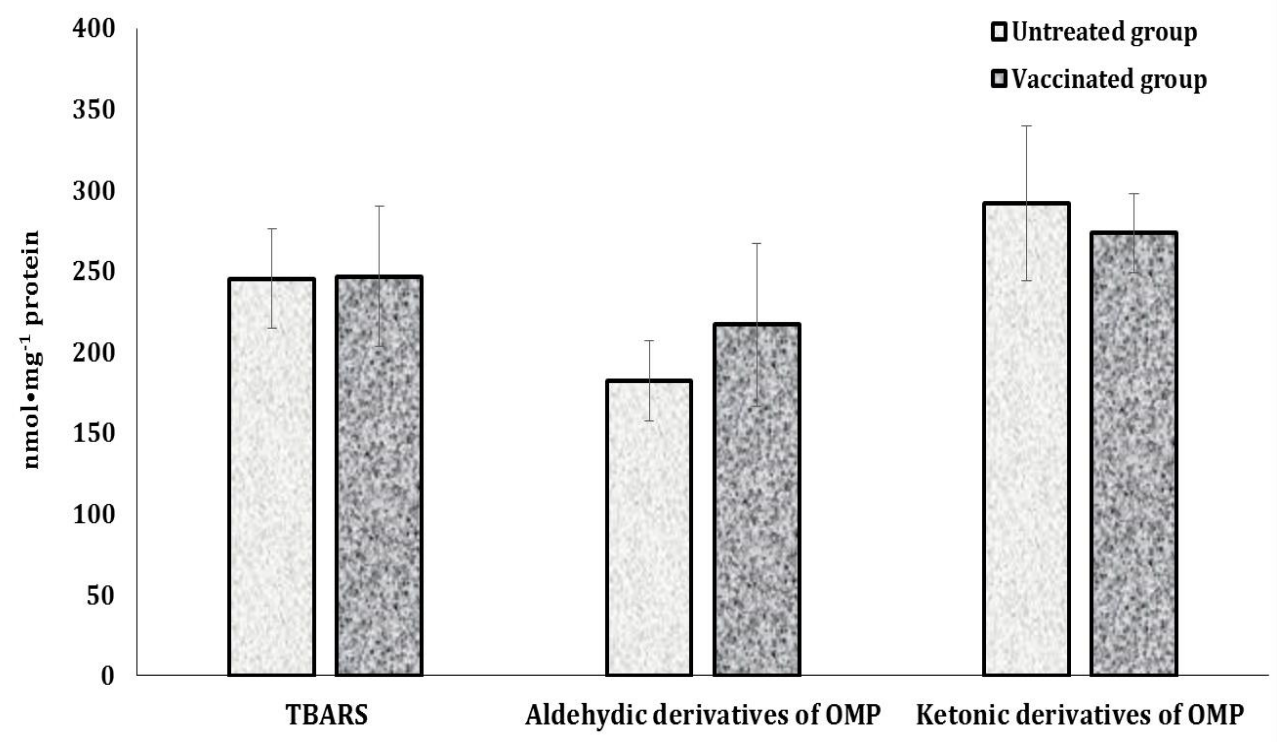

Fig. 1. The TBARS level as a biomarker of lipid peroxidation $\left(\mathrm{nmol}^{\circ} \mathrm{mg}^{-1}\right.$ protein), aldehydic and ketonic derivatives of oxidatively modified proteins (nmol $\cdot \mathrm{mg}^{-1}$ protein) in the gills of the trout treated by the vaccine against $Y$. ruckeri at second months after immunization. Data are represented as mean \pm S.E.M. $(\mathbf{n}=15)$.

Reactive oxygen species (ROS) production contributes to the elimination of pathogens and induces activation of immune defense mechanisms [23]. However, excessive ROS formation can induce oxidative stress, leading to cell damage and cell death may follow [25]. ROS comprises both free radical and non-free radical oxygencontaining molecules such as hydrogen peroxide $\left(\mathrm{H}_{2} \mathrm{O}_{2}\right)$, superoxide $\left(\mathrm{O}_{2}{ }^{-}\right)$, singlet oxygen $\left({ }^{1} \mathrm{O}_{2}\right)$, and the hydroxyl radical $(\cdot \mathrm{OH})$ [25]. Lipid peroxidation of polyunsaturated lipids is a preferred method for marking oxidative stress levels [27]. The product of lipid peroxidation, malonic dialdehyde, is easily detected in blood/plasma and has been used as a measure of oxidative stress [27]. The oxidative modification of proteins by ROS is implicated in the etiology or progression of diseases [19]. An increase in the rate of their production or a decrease in their rate of scavenging will increase the oxidative modification of cellular molecules, including proteins, and will disrupt cellular function either by the loss of catalytic and structural integrity or by interruption of regulatory pathways [31]. For the most part, oxidatively modified proteins are not repaired and must be removed by proteolytic degradation, a process that normally proceeds very efficiently from microorganisms to mammals [19]. The level of these modified molecules can be quantitated by measurement of the protein carbonyl content. It is the most widely used marker of oxidative modification of proteins [5].

In the current study, the most widely used and accepted markers were utilized to demonstrate the existence of oxidative stress in the gill tissue (TBARS as marker of lipid peroxidation, aldehydic and ketonic derivatives of OMP). In this study, our results demonstrated that immunization by the anti-Yersinia vaccine does not alter the gills of rainbow trout. Oxidative stress parameters examined in gills homogenate i.e., lipid peroxidation as measured by the amount of TBARS, as well as aldehydic (increased by $18.9 \%$ ) and ketonic derivatives of OMP (decreased by $6.5 \%$ ) were non-significantly changed ( $>>0.05)$ in gills of vaccinated fish (Fig. 1). 
In our previous study, we have also assessed the influence of vaccination against ERM disease on oxidative stress biomarkers and antioxidant defense in the muscle tissue of rainbow trout vaccinated against $Y$. ruckeri in the first and second month after immunization $[33,35]$. No significant difference was noted in lipid peroxidation level in either the first or second month after vaccination, while aldehydic and ketonic derivatives of OMB in the vaccinated group were significantly lowered in the second month compared to those in the first month after vaccination $(\mathrm{p}<0.05)$. The content of ketonic derivatives of $\mathrm{OMB}$ in muscles in the first month after immunization was higher compared to untreated controls. All these culminated in a depletion of glutathione peroxidase (GPx) activity and a low level of total antioxidant capacity (TAC). Correlations between catalase activity and lipid peroxidation and TAC confirmed the pivotal role of catalase in antioxidant defense during immunization [35]. Moreover, a statistically significant reduction in lipid peroxidation between the mean in groups immunized at the first and second months after vaccination indicated effective adaptive antioxidant defense mechanisms of fish for the immunity against $Y$. ruckeri. A similar reduction of lipid peroxidation between the mean in the control group of fish after the first and second months of the study was observed $[33,35]$.

Reducing aldehydic and ketonic derivatives of oxidatively modified proteins in the liver of vaccinated trout after two months after immunization was caused by a high antioxidant capacity of the liver [36]. Activation of proteolytic degradation of the modified amino acid residues may be one reason for the reduction of oxidatively modified derivatives resulting from adaptation to the immunization. A high level of TAC in the liver of individuals from control and immunized groups in the second month after vaccination indicated the powerful adaptability of the liver, helping defend against oxidative stress induced by immunization $[34,36]$. The increased aspartate aminotransferase activity in the liver of individuals from control and immunized groups in the second month was noted. Activation of aminotransferases indicates the metabolic transformations of proteins and carbohydrates [36]. The significant decrease in the lactate concentration and lactate dehydrogenase activity in hepatic tissue reflects the dynamic alterations in aerobic-anaerobic and aerobic metabolism as well as in the total energy supply. A significant decrease in the lactate level in hepatic tissue in the second month of the study both in the control and immunized groups indicates the proper functioning of the mechanisms of metabolic activity in the long-term effects of the vaccination. The decrease of pyruvate and lactate levels in hepatic tissue both in control and immunized groups in the second month after vaccination confirms the high adaptive capacity of the liver in compensation of metabolic alterations occurring as a result of immunization. Correlative dependence between levels of oxidative stress markers and metabolites in the liver of rainbow trout immunized with the vaccine against $Y$. ruckeri at first and second months after vaccination confirms the important role of metabolites and enzymes of energy transformation in the liver as the response to oxidative stress caused by immunization against $Y$. ruckeri [36].

To determine the effects of vaccination against $Y$. ruckeri on the health condition of rainbow trout in general, and oxidative stress biomarkers and metabolic parameters specifically, as well as to identify mechanisms that underpin the susceptibility of fish to vaccination, we compared the liver and heart function, and the oxidative mechanism underlying those effects, by detecting relevant lipid peroxidation and protein oxidation biomarkers, as well as aerobic-anaerobic metabolism in trout immunized against $Y$. ruckeri at 30 days post-vaccination and healthy individuals [34]. In our study, hepatic aminotransferase activities were positively associated with the oxidative stress biomarkers in the trout vaccinated against $Y$. ruckeri. Moreover, similar associations were 
observed in the cardiac tissue of the immunized trout. Decreased aldehydic and ketonic derivatives of oxidatively modified proteins and the reduction of aminotransferases and lactate dehydrogenase activities were sensitive to vaccination of trout against $Y$. ruckeri and may potentially be used as biomarkers in evaluating vaccine effects in the liver of rainbow trout. Understanding the role of biochemical changes in the tissues of vaccinated trout has important implications for the understanding of the complex physiological changes that occur in immunization but also for improving aquaculture practices to maximize tissue growth and health of vaccinated trout $[34,36]$.

The fish gill is the most physiologically diversified vertebrate organ, and its vasculature is the most intricate. Many of the anatomical characteristics of interlamellar vessels are strikingly similar to those of mammalian lymphatic capillaries, with the exception that interlamellar vessels are directly fed by arteriovenous-like anastomoses. Gill interlamellar and mammalian lymphatics are likely physiologically equivalent [21]. Small and large lymphocytes, macrophages, neutrophils, eosinophilic granulocytes, and antibody-secreting cells have been observed in the gill-associated lymphoid tissue of different fish species [30]. IgM+ cells (B-cells, plasma cells, and IgM-bearing macrophages) are very abundant in the stratified epithelium of the gill arch and filaments [12]. The study of dos Santos and co-workers (2001) strongly supports the importance of the route of immunization to locally stimulate antibody-secreting cells in gills and the importance that the gills might have in specific responses [6]. In addition to the lymphoid tissue found within the gill lamellae, an interbranchial lymphoid tissue has been recently described in salmonids $[14,17]$. Therefore, as the first-line encounter towards antigens, the epithelium of the gills and intestines are important locations for immune reactions. These sites should likely display the first phylogenetic signs of immune cell compartmentalization [14].

Microbe recognition sets the immune system in motion, and ROS are produced not only in the phagocyte respiratory burst but also in other cell compartments, such as mitochondria, as intermediaries in many signal transduction pathways, such as leukocyte pattern recognition receptor (PRR) signaling. The generation of ROS is a prerequisite to the formation of mechanisms that promote microbe clearance, whereas others can potentially contribute to microbe persistence [23]. At moderate concentrations, ROS play an important role as regulatory mediators in signaling processes. Many of the ROS-mediated responses protect the cells against oxidative stress and reestablish "redox homeostasis". At high concentrations, ROS are hazardous for cells and damage all major cellular constituents [7].

Conclusions. In summary, the findings described in the present study allow the conclusion that immunization by anti-Yersinia vaccine does not alter oxidative stress markers compared to unhandled control in the second month after immunization. From a broader perspective, it is suggested that immunization of fish by anti-Yersinia vaccine is associated with the induced free radical formation and oxidative stress. Free radicals would, therefore, be at least partially responsible for immunity with humoral and cellular elements and increased protective immunity against $Y$. ruckeri infection. Our results confirm that the vaccine against $Y$. ruckeri has no adverse effect on the condition and metabolism in the gills of the fish. Metabolic alterations recorded in our studies are proof that the vaccine against $Y$. ruckeri has no negative effects.

\section{References}

1. Barnes, A. C. (2011). Enteric Redmouth Disease (ERM) (Yersinia ruckeri). Fish Diseases and Disorders, Volume 3: Viral, Bacterial and Fungal Infections, $2^{\text {nd }}$ Ed., P.T.K. Woo, D.W. Bruno (Eds). MPG Books Group, UK. 
2. Bradford, M. M. (1976). A rapid and sensitive method for the quantitation of microgram quantities of protein utilizing the principle of protein-dye binding. Anal. Biochem., 72, 248-254.

3. Bruno, D. (1990). Enteric Redmouth Disease; Aquac. Inf. Ser. Available online: https://www2.gov.scot/Topics/marine/science/Publications/FRS-Reports/ais.

4. Bullock, G. (1989). Enteric Redmouth Disease. Fish Heal. Bull., Available online : https://apps.dtic.mil/dtic/tr/fulltext/u2/a322943.pdf.

5. Chevion, M., Berenshtein, E., \& Stadtman, E. R. (2000). Human studies related to protein oxidation: protein carbonyl content as a marker of damage. Free Radic. Res., 33 (Suppl.), S99-S108.

6. Dos Santos, N. M., Taverne-Thiele, J. J., Barnes, A. C., van Muiswinkel, W. B., Ellis, A. E., \& Rombout, J. H. (2001). The gill is a major organ for antibody secreting cell production following direct immersion of sea bass (Dicentrarchuslabrax, L.) in a Photobacteriumdamselae ssp. Piscicidabacterin : an ontogenetic study. Fish Shellfish Immunol., 11(1), 65-74.

7. Dröge, W. (2002). Free radicals in the physiological control of cell function. Physiol. Rev., 82(1), 47-95.

8. Dubinina, E. E., Burmistrov, S. O., Khodov, D. A., Porotov, I. G. (1995). Okislitel'naia modifikatsiia belko v syvorotki krovi cheloveka, metode e opredeleniia [Oxidative modification of human serum proteins. A method of determining it]. Vopr. Med. Khim., 41(1), 24-26 [in Russian].

9. Ewing, W. H., Ross, A. J., Brenner, D. J., Fanning, G. R. (1978). Yersinia ruckerisp. nov. Redmouth (rm) bacterium. International Journal of Systematic Bacteriology, 28(1), 37-44.

10. From, J., Rasmussen, G. (1984). A growth model, gastric evacuation, and body composition in rainbow trout, Salmo gaidneri Richardson 1836. Dana, 3, 61-139.

11. Fuhrmann, H., Böhm, K., \& Schlotfeldt, H. (1983). An outbreak of enteric red mouth disease in West Germany. J. Fish Dis., 6, 309-311.

12. Grove, S., Johansen, R., Reitan, L. J., \& Press, C.M. (2006). Immune- and enzyme histochemical characterization of leukocyte populations within lymphoid and mucosal tissues of Atlantic halibut (Hippoglossushippoglossus). Fish Shellfish Immunol., 20(5), 693-708.

13. Harun, N. O., Wang, T., \& Secombes C. J. (2011). Gene expression profiling in naïve and vaccinated rainbow trout after Yersinia ruckeriinfection : insights into the mechanisms of protection seen in vaccinated fish. Vaccine, 29(26), 4388-4399.

14. Haugarvoll, E., Bjerkås, I., Nowak, B.F., Hordvik, I., \& Koppang, E. O. (2008). Identification and characterization of a novel intraepithelial lymphoid tissue in the gills of Atlantic salmon. J. Anat. 213(2), 202-209.

15. Jaafar, R. M., Al-Jubury, A., Dalsgaard, I., Mohammad Karami, A., Kania, P.W., \& Buchmann, K. (2019). Effect of oral booster vaccination of rainbow trout against Yersinia ruckeri depends on type of primary immunization. Fish Shellfish Immunol., 85, 61-65.

16. Kamyshnikov, V. S. (2004). A reference book on the clinic and biochemical researches and laboratory diagnostics. MED press-inform, Moscow [in Russian].

17. Koppang, E. O., Fischer, U., Moore, L., Tranulis, M. A., Dijkstra, J. M., Köllner, B., Aune, L., Jirillo, E., \& Hordvik, I. (2010). Salmonid T cells assemble in the thymus, spleen and in novel interbranchial lymphoid tissue. J. Anat., 217(6), 728-739.

18. Kumar, G., Menanteau-Ledouble, S., Saleh, M., \& El-Matbouli, M. (2015). Yersinia ruckeri, the causative agent of enteric Redmouth disease in fish. Vet. Res., 46(1), 103. 
19. Levine, R. L. (2002). Carbonyl modified proteins in cellular regulation, aging, and disease. Free Radic. Biol. Med., 32(9), 790-796.

20. Levine, R. L., Garland, D., Oliver, C. N., Amici, A., Climent, I., Lenz, A.-G., Ahn, B.-W., Shaltiel, S., \& Stadtman, E. R. (1990). Determination of carbonyl content in oxidatively modified proteins. Methods Enzymol., 186,465-478.

21. Olson, K. R. (2002). Vascular anatomy of the fish gill. J. Exp. Zool., 293 (3), 214-231.

22. Ormsby, M. J., Caws, T., Burchmore, R., Wallis, T., Verner-Jeffreys, D. W., \& Davies, R. L. (2016). Yersinia ruckeri Isolates Recovered from Diseased Atlantic Salmon (Salmo salar) in Scotland Are More Diverse than Those from Rainbow Trout (Oncorhynchus mykiss) and Represent Distinct Subpopulations. Appl. Environ. Microbiol., 82 (19), 5785-5794.

23. Paiva, C. N., \& Bozza, M. T. (2014). Are reactive oxygen species always detrimental to pathogens? Antioxid. Redox Signal., 20(6), 1000-1037.

24. Pękala, A., Antychowicz, J. (2010). Yersiniosis of salmonids epizootiology of the disease, methods of its elimination. Medycyna Wet., 66 (6), 374377

25. Poljsak, B., Šuput, D., \& Milisav, I. (2013). Achieving the balance between ROS and antioxidants: when to use the synthetic antioxidants. Oxid. Med. Cell Longev., 2013, 956792.

26. Quentel, C., \& Vigneulle, M. (1997). Antigen uptake and immune responses after oral vaccination. Dev. Biol. Stand., 90, 69-78.

27. Rahal, A., Kumar, A., Singh, V., Yadav, B., Tiwari, R., Chakraborty, S., \& Dhama, K. (2014). Oxidative stress, prooxidants, and antioxidants: the interplay. Biomed. Res. Int., 2014, 761264.

28. Raida, M. K., Nylén, J., Holten-Andersen, L., \& Buchmann, K. (2011). Association between plasma antibody response and protection in rainbow trout Oncorhynchus mykiss immersion vaccinated against Yersinia ruckeri. PLoS One, 6 (6), e18832.

29. Ross, A. J., Rucker, R. R., \& Ewing, W. H. (1966). Description of a bacterium associated with Redmouth disease of rainbow trout (Salmo gairdneri). Can. $J$. Microbiol., 12 (4), 763-770.

30. Salinas, I., Zhang, Y. A., \& Sunyer, J. O. (2011). Mucosal immunoglobulin's and B cells of teleost fish. Dev. Comp. Immunol., 35(12), 13461365.

31. Stadtman, E. R., Levine, R. L. (2000). Protein oxidation. Ann. NY Acad. Sci., 899, 191-208.

32. Thompson, K. D., Adams, A. (2004). Current Trends in Immunotherapy and Vaccine Development for Bacterial Diseases of Fish. Current trends in the study of bacterial and viral fish and shrimp diseases / Ed. Ka Yin Leung (Molecular aspects of fish and marine biology; V. 3), World Scientific Publishing Co. Pte. Ltd., Singapore, pp. 313-362.

33. Tkachenko, H., Grudniewska, J., Pękala, A. (2016). Muscle biochemistry in rainbow trout Oncorhynchus mykiss following Yersinia ruckeri vaccination. Baltic Coastal Zone - Journal of Ecology and Protection of the Coastline, 20, 137-159.

34. Tkachenko, H., Grudniewska, J., Pękala, A., \& Paździor, E. (2016). Effects of vaccination against Yersinia ruckeri on oxidative stress biomarkers and liver and heart biochemistry in rainbow trout (Oncorhynchus mykiss). Arch. Pol. Fish., 24, 3346. 
35. Tkachenko, H., Grudniewska, J., Pękala, A., \& Terech-Majewska, E. (2016). Oxidative stress and antioxidant defense markers in muscle tissue of rainbow trout (Oncorhynchus mykiss) after vaccination against Yersinia ruckeri. J. Vet. Res., 60, $25-33$.

36. Tkachenko, H., Komorowski, I., Grudniewska, J., \& Kurhaluk, N. (2015). Przemiany metaboliczne w wątrobie pstrąga tęczowego (Oncorhynchusmykiss, Walbaum) immunizowanego szczepionką przeciwko Yersiniaruckeri. Stupskie Prace Biologiczne, 12, 367-391.

37. Welch, T. J., \& LaPatra, S. (2016). Yersinia ruckeri lipopolysaccharide is necessary and sufficient for eliciting a protective immune response in rainbow trout (Oncorhynchus mykiss, Walbaum). Fish Shellfish Immunol., 49, 420-426.

38. Wrobel, A., Leo, J.C., \& Linke, D. (2019). Overcoming Fish Defences : The Virulence Factors of Yersinia ruckeri. Genes (Basel), 10(9), 700.

39. Zar, J. H. (1999). Biostatistical Analysis. $4^{\text {th }}$ ed., Prentice Hall Inc., Englewood Cliffs, New Jersey.

ПОСТВАКЦИНАЛЬНЫЕ ИЗМЕНЕНИЯ МАРКЕРОВ ОКИСЛЕНИЯ ЛИПИДОВ И БЕЛКОВ В ЖАБРАХ РАДУЖНОЙ ФОРЕЛИ (ONCORHYNCHUS MYKISS WALBAUM) ИММУНИЗИРОВАННОЙ ПРОТИВ YERSINIA RUCKERI

Ткаченко Г., Кургалюк Н., Институт биологии и наук о Земле, Поморская Академия в Слупске, Польша

Грудневская И., Институт внутреннего рыболовства им. Станислава Саковича, Жуково, Польша

Пенкала-Сафинская А., Национальный исследовательский ветеринарный институт, Пулавы, Польша

Целью исследования была оченка содержания биомаркеров окислительного стресса (веществ, реагирующих с 2-тиобарбитуровой кислотой как биомаркер перекисного окисления липидов, альдегидных и кетоновых производных окислительно модифицированньх белков) в жабрах радужной форели (Oncorhynchus mykiss Walbaum) вакцинированной против Yersinia ruckeri.

В экспериментах использовалась радужная форель (Oncorhynchus mykiss Walbaum) со средней массой тела $(107,9 \pm 3,1)$ г. Исследование проводилось в отделе изучения лососевых рыб Института внутреннего рыболовства в Рутках (Польша). Эксперименты проводились при температуре воды $14,5 \pm 0,5{ }^{\circ} \mathrm{C}$ и pH 7,5. Уровень растворенного кислорода составлял около 12 мг/л при дополнительной подаче кислорода с потоком воды 25 л в минуту, фотопериодом 12 часов в день. Рыбу кормили коммерческой гранулированной диетой на оптимальном уровне с использованием 12-часовых ленточных кормушек для рыбы. Все ферментативные анализы проводились на кафедре зоологии и физиологии животных Института биологии и наук о Земле Поморского университета в Слупске (Польша). После вакцинации рыб содержали в течение 60 дней при температуре воды $14,5 \pm 0,5{ }^{\circ} \mathrm{C}$ и рН 7,5. В нашем исследовании было использовано 15 радужных форелей из необработанного контроля и 15 вакиинированных форелей. Через два месяца после иммунизации были отобраны образиы радужной форели. Рыбы были пойманы и умерщьвлены через 61 день после вакциначии ( $n=15$ в каждой группе). Жабры удалены на месте. Органы промывали от крови холодным буфером для выделения и гомогенизировали, используя стеклянный гомогенизатор H500 с приводимым в движение пестиком, погруженным в баню с ледяной водой, с получением гомогената в соотношении 1: 9 (вес / объем). Буфер для выделения содержал 100 мМ Tрис-HCl; pH 7,2 доводили с помощьюю $\mathrm{HCl}$. Гомогенаты ичен- 
трифугировали при $3000 \mathrm{~g}$ в течение 15 мин при $4{ }^{\circ} \mathrm{C}$. После иентрифугирования супернатант собирали и замораживали при $-20^{\circ} \mathrm{C}$ до анализа. Содержание белка определяли по методу Брэдфорда (1976) с использованием бычьего сывороточного альбумина в качестве стандарта. Поглощение регистрировали при 595 нм. Все ферментативные анализы проводили при $22 \pm 0,5{ }^{\circ}$ C с использованием спектрофотометра Specol 11 (Carl Zeiss Jena, Германия) в двух экземплярах. Ферментативные реакции запускали добавлением тканевого супернатанта.

Наши результаты показали, что иммунизачия не изменяет жабры радужной форели. Параметры окислительного стресса, исследованные в гомогенате жабр, т. е. перекисное окисление липидов, измеряемое по количеству веществ, реагирующих с 2-тиобарбитуровой кислотой, а также альдегидных (увеличение на 18,9\%) и кетоновых производных окислительно модифицированных белков (уменьшение на 6,5\%), изменились незначительно $(p>0,05)$ в жабрах вакцинированной рыбыл. Таким образом, иммунизация вакциной против Yersinia не изменяет содержания биомаркеров окислительного стресса по сравнению с необработанным контролем на второй месяи после иммунизации. Наши результаты подтверждают, что вакиина против Y. ruckeri не оказывает вредного воздействия на состояние и метаболизм в жабрах рыб. Изменения содержания биомаркеров окислительного стресса доказывают, что вакичина против Y. ruckeri не имеет отрииательных эффектов.

Ключевые слова: Yersinia ruckeri, радужная форель (Oncorhynchus mykiss Walbaum), жабры, пероральная вакиинация, вещества, реагирующие $c$ 2-тиобарбитуровой кислотой, альдегидные и кетоновые производные окислительно модифицированных белков.

ПОСТВАКЦИНАЛЬНІ ЗМІНИ МАРКЕРІВ ОКИСЛЕННЯ ЛІПІДІВ I БІЛКІВ ЖАБЕР РАЙДУЖНОЇ ФОРЕЛІ (ONCORHYNCHUS MYKISS WALBAUM) IMУНIЗУВАНОÏ ПРОТИ YERSINIA RUCKERI

Ткаченко Г., Кургалюк Н., Інститут біологї̈ та наук про Землю, Поморська Академія в Слупську, Польщза

Грудневская I., Інститут внутрішнього рибальства ім. Станіслава Саковича, Жуково, Польщза

Пенкала-Сафінская А., Начіональний дослідниџький ветерина-нарний інститут, Пулави, Польща

Метою дослідження була оцінка вмісту біомаркерів окислювального стресу (речовин, що реагують з 2-тіобарбітурової кислотою як біомаркер перекисного окислення ліпідів, альдегідних і кетонових похідних окислювально модифікованих білків) в жабрах райдужної форелі (Oncorhynchus mykiss Walbaum) вакцинованої проти Yersinia ruckeri.

В експериментах використовувалася райдужна форель (Oncorhynchus mykiss Walbaum) із середньою масою тіла $(107,9 \pm 3,1)$ г. Дослідження проводилося в відділі вивчення лососевих риб Інституту внутрішнього рибальства в Рутках (Польща). Експерименти проводилися при температурі води $14,5 \pm 0,5{ }^{\circ} \mathrm{C} i$ pH 7,5. Рівень розчиненого кисню становив близько 12 мг/л при додатковій подачі кисню з потоком води 25 л в хвилину, фотоперіодом 12 годин на добу. Рибу годували комериійної гранульованої дієтою на оптимальному рівні з використанням 12-годинних стрічкових годівниць для риби. Всі ферментатівние аналізи проводилися на кафедрі зоологї та фізіологї тварин Інституту біології та наук про Землю Поморського університету в Слупську (Польша). Після вакцинації риб утримували протягом 60 днів при температурі води $14,5 \pm 0,5{ }^{\circ} \mathrm{C}$ і рH 7,5. У намому 
дослідженні було використано 15 райдужних форелей необробленого контролю $i$ 15 вакцинованих форелей. Через два місячі після імунізації були відібрані зразки райдужної форелі. Риба була спіймана та убита через 61 день після вакииначії ( $n=15$ у кожній групі). Зябра видалені на місці. Органи промивали від крові холодним буфером для виділення $і$ гомогенізували, використовуючи скляний гомогенізатор Н500 з рухомим товкачем, зануреним в баню з крижаною водою, з отриманням гомогенної речовини у співвідноменні 1: 9 (вага / об'єм). Буфер для виділення характеризувався $100 \mathrm{mM} \mathrm{Tpic-HCl;} \mathrm{pH} \mathrm{7,2} \mathrm{доводили} \mathrm{за} \mathrm{допомогою} \mathrm{HCl}$. Гомогенати иінтрифугували при $3000 \mathrm{~g}$ протягом 15 хв при $4{ }^{\circ} \mathrm{C}$. Після иеентрифугування супернатант збирали $i$ заморожували при $-20{ }^{\circ} \mathrm{C}$ до аналізу. Вміст білку визначали за методом Бредфорда (1976) з використанням бичачого альбуміну сироватки в якості стандарту. Поглинання реєстрували при 595 нм. Всі ферментативні аналізи проводили при $22 \pm 0,5{ }^{\circ} \mathrm{C}$ з використанням спектрофотометра Specol 11 (Carl Zeiss Jena, Німеччина) в двох повторностях. Ферментативні реакиї запускали додаванням тканинного супернатанта.

Наші результати показали, щз імунізація не змінює жабри райдужної форелі. Параметри окисного стресу, досліджені в гомогенаті жаьер, тобто перекисне окислення ліпідів, щуо вимірюється за кількістю речовин, що реагують з 2тіобарбітуровою кислотою, а також альдегідних (збільшилося на 18,9 \%) $і$ кетонових похідних окислювально модифікованих білків (зменшилося на 6,5 \%), змінилися незначно $(p>0,05)$ в жабрах вакцинованих риб. Таким чином, імунізація вакциною проти Үегsinia не змінюе вмісту біомаркерів окисного стресу в порівнянні з необробленим контролем на другий місящь після імунізаиії. Наші результати підтверджують, щзо вакиина проти Y. ruckeri не робить шкідливого впливу на стан і метаболізм в жабрах риб. Зміни вмісту біомаркерів окисного стресу доводять, щзо вакиина проти Y. ruckeri не має негативних ефектів.

Ключові слова: Yersinia ruckeri, райдужна форель (Oncorhynchus mykiss Walbaum), жабра, пероральна вакциначія, речовини, що реагують 3 2тіобарбітурової кислотою, альдегідні і кетонові похідні окислювально модифікованих білків.

UDC636.1.083.38:591.1

DOI 10.32900/2312-8402-2020-124-35-46

\title{
EXERCISE-INDUCED CHANGES IN THE LEVEL OF TOTAL PROTEIN AND ITS FRACTIONS IN THE BLOOD OF HORSES INVOLVED IN RECREATIONAL HORSEBACK RIDING
}

\author{
Tkachenko H., Doctor of Biological Sciences
}

Kurhaluk N., Doctor of Biological Sciences

Institute of Biology and Earth Sciences, Pomeranian University in Słupsk

Tkachova I., Doctor of Agricultural Sciences

The Institute of Animal Science NAAS, Kharkiv, Ukraine

The aim of the current study was to do the analysis of the total protein and its fraction in the blood samples of horses, which are involved in recreational horseback riding in the Pomeranian region (Pomeranian Voivodship, northern Poland).

Thirteen healthy adult horses from the Pomeranian region in Poland (Strzelinko

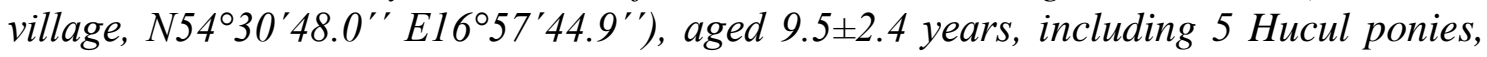

